\title{
SYTUACJA, PRZEŻYCIA ORAZ POTRZEBY ZDROWEGO RODZEŃSTWA W RODZINACH Z DZIECKIEM PRZEWLEKLE CHORYM
}

\section{Streszczenie}

Niniejszy artykuł podejmuje dość rzadko poruszany w literaturze temat, jakim jest sytuacja życiowa, przeżycia oraz potrzeby u rodzeństwa dzieci, u których zdiagnozowano chorobę przewlekłą.

Opisano definicyjne ujęcie podejścia do choroby przewlekłej, w szczególny sposób opierając się na terminologii w ujęciu potocznym, medycznym, psychologicznym oraz socjologicznym. Ponadto poruszona została tematyka sytuacji oraz przeżyć, jakich doświadcza rodzina, w której pojawia się choroba przewlekła jednego z członków, ze szczególnym uwzględnieniem rodzeństwa dzieci chorych. Znaczną część artykułu zajmują zagadnienia dotyczące potrzeb sióstr i braci dzieci cierpiących na długotrwałe, poważne schorzenia somatyczne.

W konkluzji autorka podkreśla rolę rodziców w kształtowaniu prawidłowych wzorów radzenia sobie w sytuacjach trudnych, kształtowania samooceny oraz zaspokajania potrzeb swoich dzieci, zarówno tych chorych jak i ich rodzeństwa.

Słowa kluczowe: choroba przewlekła, potrzeby, rodzina, rodzeństwo

\section{Wprowadzenie}

Zagadnienia dotyczące sytuacji, przeżyć oraz potrzeb członków rodzin, w których obecna jest przewlekła choroba somatyczna, są niezwykle delikatną, ale i ze względu na swoją specyfikę trudną dziedziną. Wiadomym jest, iż choroba przewlekła w rodzinie dotyka w szczególny sposób nie tylko cierpiącą osobę, ale także pozostałych członków rodziny. 
Niniejszy artykuł traktuje o sytuacji, przeżyciach, a także potrzebach, jakie odczuwają zdrowe siostry i bracia dzieci przewlekle chorych. Nie ulega wątpliwości, że sytuacja w rodzinach, w których pojawiła się choroba przewlekła jednego z jej członków, jest odmienna i wymaga specyficznego funkcjonowania i adaptacji. Ponadto, długotrwała dysfunkcja somatyczna generuje specyficzne przeżycia, niekiedy bardzo obciążające. Dodatkowo warto nadmienić, iż rodzeństwo dzieci cierpiących z powodu długotrwałych dysfunkcji somatycznych, szczególnie tych zagrażających życiu, podobnie jak każde inne dzieci, ma swoje potrzeby, których zaspokojenie wymaga uwagi i działania dorosłych.

Choroba wyzwala szereg trudności i konsekwencji, które wymagają szczególnego dostrzeżenia i pomocy, zarówno tej logicznej, ale także opierającej się na wspieraniu emocjonalnym. Zagadnienie to zdaje się być ważne w rozważaniach zarówno natury naukowej, jak i praktycznej.

\section{Choroba przewlekła - ujęcie definicyjne i jej następstwa}

Mimo oczywistych osiągnięć nauki i nieustannie postępującego rozwoju gałęzi medycyny, w dalszym ciągu człowiek nie może całkowicie poradzić sobie z zagrożeniami zdrowia, a co za tym idzie, nie jest w stanie skutecznie zlikwidować chorób nękających ludzkość (Lipińska-Lokś, 2012).

Różnorodne choroby towarzyszą człowiekowi od zarania dziejów. W dawnych czasach ludzie cierpieli z powodu dolegliwości somatycznych, poddawali się rozmaitym formom leczenia i terapii, a niekiedy nawet w konsekwencji poważnego wyniszczenia organizmu umierali. Co ciekawe, w starożytności osoby poważnie cierpiące z powodu dysfunkcji somatycznych oraz starsze były oddalane na margines życia społeczeństwa. Co więcej, choroba według tamtejszych wierzeń była karą zsyłaną na człowieka przez bogów. Dopiero cywilizacja chrześcijańska i jej wartości dokonały przełomu w podejściu do cierpienia. Skutkowało to zainteresowaniem i „pomocą bliźniemu”, a szczególnie osobom chorym będącym w potrzebie (http:// www.wiecjestem.us.edu.pl/opieka-paliatywna-i-hospicyjna-czlowiek-w-obliczunieuleczalnej-choroby-czesc-i, dostęp: dn. 03.11.2019). Na początku XX wieku, najczęściej występującymi poważnymi, nieuleczalnymi chorobami były zwykle prowadzące do zgonów ciężkie przypadku grypy, tyfusu czy gruźlicy (Jachimczak, 2011). Choroby te nękały ludzi przez wiele wieków, ograniczając możliwości rozwoju i edukacji.

W literaturze, zwłaszcza medycznej, dostępnych jest wiele opracowań dotyczących choroby przewlekłej i funkcjonowania osób dotkniętych poważnymi schorzeniami somatycznymi. Jednak z uwagi na wielowymiarowość, zmienność rokowań, 
przebiegu i znaczną złożoność problemów zdrowia nie ustalono jednej, uniwersalnej definicji choroby (Lipińska-Lokś, 2012).

Chorobę oraz jej skutki można ujmować w różnym rozumieniu, między innymi: potocznym, biologiczno-medycznym, psychologicznym, ale także socjologicznym. Każde z tych podejść prowadzi do naukowej refleksji, a także działań praktycznych, które ukierunkowane są na oddziaływanie pomocowe, mające na celu poprawę jakości życia i funkcjonowania cierpiących osób.

Źródła encyklopedyczne określają chorobę jako dynamiczną reakcję organizmu na działanie czynników chorobotwórczych, która objawia się utrudnionym funkcjonowaniem i współdziałaniem narządów i tkanek (Maciarz, 1996, za: Lipińska-Lokś, 2012).

Potocznie choroba oznacza ogólny zły stan zdrowia fizycznego, psychicznego, któremu towarzyszy także konieczność specjalistycznej pomocy farmakologicznej, lekarskiej, psychologicznej czy też społecznej (Łuczak, 2003, za: Lipińska-Lokś, 2012). Kojarzona jest wprost z dysfunkcją organizmu, uniemożliwiającą realizację zadań życia codziennego i pełnego uczestnictwa w życiu społecznym.

W rozumieniu biologicznym, uwaga oraz oddziaływanie ukierunkowane jest na fizjologiczną stronę przebiegu oraz konsekwencji choroby. W tym ujęciu istnieją różne sposoby klasyfikacji chorób, zarówno w medycynie, jak i dziedzinach nauk społecznych, m.in. choroby mogą być określane ze względu na przyczynę, sposób przenoszenia, i tak dla przykładu są to choroby zakaźne lub niezakaźne, ale także na zajęcie określonych układów lub narządów, takie jak np. choroby układu krążenia (Topór-Mądry, 2011).

Jednym z najczęściej używanych systemów klasyfikacji choroby jest podział na kategorie: choroby ostre i choroby przewlekłe. Termin „ostre” (łac. acutus) został zastosowany do stanów chorobowych ocenianych według trzech parametrów, mianowicie: krótkiego okresu trwania choroby, szybkiego początku oraz znacznego nasilenia objawów chorobowych.

W przeciwieństwie do powyższego, będące tematem niniejszego artykułu choroby przewlekłe (łac. chronicus, oznaczający ciągły lub stały) są chorobami, które z reguły mają długi czas trwania, powolny początek, ale także mniejsze nasilenie objawów chorobowych (Topór-Mądry, 2011).

Dodatkowo, w omawianym ujęciu biologicznym należy określić, iż choroby przewlekłe charakteryzują się przede wszystkim:

- czasem trwania od co najmniej czterech tygodniu (Maciarz, 2003, za: Olszewski, Parys, 2016);

- łagodniejszym przebiegiem,

- nieodwracalnością zmian patologicznych, a co za tym idzie, choroby przewlekłe mogą prowadzić do kalectwa i znacznych zmian w narządach oraz tkankach; 
- konieczność długotrwałej opieki medycznej o odpowiednio przygotowanej i prowadzonej rehabilitacji (Pilecka, 2002; Maciarz, 2003 za: Olszewski, Parys, 2016).

Warto również nadmienić, iż choroby przewlekłe są częstą przyczyną zgonów, które następują wcześniej niż u osób niedotkniętych schorzeniem, ale także wcześniej niż w typowym wieku życia.

W trochę odmienny sposób odbywało się będzie dokonywanie charakterystyki chorób przewlekłych u dzieci. W tym przypadku określanie choroby przewlekłej nie jest łatwym zadaniem, opiera się często na opisach chorób obecnych już od narodzin, takich jak choroby genetyczne, metaboliczne czy poważne wady rozwojowe (Bohdan, 2012). Dodatkowo do tych chorób dołącza się schorzenia wynikające z nieprawidłowego przebiegu porodu, urazów okołoporodowych, niedotlenienia czy choroby matki oraz jej leczenia. Inne schorzenia będą dotyczyły trwałych uszkodzeń wywołanych nieprzewidywalnymi zdarzeniami, wypadkami, urazami, zatruciami czy działaniem innych czynników zewnętrznych (Bohdan, 2012).

Choroby przewlekłe w holistycznym ujęciu, w związku z licznymi obciążeniami całego organizmu, wiążą się z trudnościami nie tylko fizjologicznymi, ale także natury psychicznej, co z kolei może mieć różnorodny, pozytywny lub negatywny wpływ na przebieg choroby, radzenie sobie z trudnościami, ale i rokowania.

W ujęciu psychologicznym choroba wiąże się z licznymi konsekwencjami i ograniczeniami, ale także silnym poczuciem dyskomfortu.

Wśród nich można wyróżnić takie następstwa jak:

- koncentracja na zaspokajaniu potrzeb podstawowych, takich jak: jedzenie, picie, ale także poczucie bezpieczeństwa, akceptacji i miłości;

- poczucie braku wpływu na zdarzenia i brak kontroli;

- poczucie wstydu, poczucie „bycia innym”;

- utrata perspektywy życiowej i nadziei na zmianę;

- poczucie zagrożenia, lęk, smutek;

- ograniczenie kontaktu ze światem zewnętrznym, symulacji przy długotrwałym odizolowaniu od społeczeństwa;

- koncentracja nad aktualną sytuacją, bycie „tu i teraz”;

- niechęć do planowania i myślenia o przyszłości (Tanajewska, Naprawa, Stawska, 2014).

W ujęciu socjologicznym choroba przewlekła będzie oznaczała przyjęcie nowej roli i odnalezienie się w innej sytuacji życiowej dla osoby cierpiącej z powodu dysfunkcji somatycznej. Będzie dotyczyła także konieczności odnalezienia się w innych przestrzeniach życiowych, w tym szpitalnych, a niekiedy nawet zawieranie nowych znajomości i budowanie odmiennych relacji społecznych. 
Poważne schorzenie somatyczne jest niewątpliwie silnie obciążające dla każdego człowieka i generuje szereg trudności. Jak twierdzą Pilecka i Pilecki (1992, za: Lipińska-Lokś, 2012), dysfunkcja somatyczna wyznacza człowiekowi odmienną pozycję $\mathrm{w}$ społeczeństwie, stawia nowe wyzwania, uruchamia odmienne reakcje indywidualne i społeczne oraz wymaga odnalezienia się w dotąd nieodstępnych instytucjach.

\section{Sytuacja oraz przeżycia rodziny i rodzeństwa dzieci przewlekle chorych}

Słowo rodzina ma korzenie prasłowiańskie i wiąże się z rzeczownikiem ród, gdyż pierwotnie służyło do określania relacji pokrewieństwa, powinowactwa (Buracka, 2017, za: Krasiejko, 2019).

Rodzina powszechnie uważana jest za źródło oraz podstawową jednostkę życiową człowieka. Dodatkowo określa się ją jako najmniejszą grupę społeczną, która w swojej istocie ma za zadanie tworzyć miniaturę szerszego społeczeństwa (Kiliszek, 2019). Rodzina może stanowić miejsce tworzenia się zasad moralnych oraz życia społecznego, w której członkowie wzajemnie oddziaływają na siebie, tworząc podstawową komórkę życiową.

Rodzina ma w swojej istocie wiele zadań oraz ról do spełnienia. Jednym z podstawowych zadań, jakie powinny być realizowane w rodzinie, winno być przygotowanie członków do właściwego funkcjonowania w społeczeństwie. Polega ono na nauczeniu dziecka samodzielnego zaspokajania potrzeb i uwrażliwieniu go na potrzeby i wartości innych osób (Ziółkowska, 2010, za: Godawa, 2013, s. 375-380).

W rodzinie, jako określonej strukturze, dokonuje się przekaz psychospołeczny oraz normatywno-kulturowy (Kiliszek, 2019). W tym celu rodzina podejmuje funkcję opiekuńczo-wychowawczą, którą można określić jako „[...] zespół podejmowanych przez rodziców w stosunku do swych dzieci różnorodnych czynności i zachowań, które prowadzą do ich nowego stanu psychofizycznego" (Kawula, 2007, za: Godawa, 2013). Można przyjąć, iż celem działalności opiekuńczej w rodzinie jest stworzenie warunków do wszechstronnego rozwoju wychowanków oraz zapobieganie sytuacjom zagrażającym ich prawidłowemu funkcjonowaniu (Godawa, 2013). Rodzina jest więc swego rodzaju miejscem treningów, odzwierciedlającym przyszłe relacje międzyludzkie, oraz obszarem, gdzie realizowane są również potrzeby związane z tworzeniem więzi, poczucia bezpieczeństwa i bliskości.

W sytuacji, gdy w rodzinie pojawia się choroba jednego z członków, najczęściej dzieje się to niespodziewanie i ma wpływ nie tylko na życie jednostki, ale i na pozostałych członków jej rodziny oraz bliskich (Krakowiak, Starkel, 2012). Pojawienie 
się w rodzinie dziecka z dysfunkcją skłania do znaczących zmian w jej sytuacji oraz postępowaniu (Doroszuk, 2017). W momencie, kiedy rodzice dowiadują się o schorzeniu swojego narodzonego dziecka, odczuwają nieodwracalną stratę, a co więcej, plany oraz marzenia muszą zostać skorygowane przez chorobę, konieczna jest duża tolerancja dla siebie i tego, co się wydarzy (Rogiewicz, Paczkowska, 2012).

W rodzinie z chorym dzieckiem wspomniane wcześniej oddziaływania opiekuńczo-wychowawcze przesuwają się w kierunku poczynań ratowniczych, interwencyjnych czy kompensacyjnych, które są istotną częścią opieki nad dzieckiem. W takiej sytuacji proces opiekuńczo-wychowawczy nabiera specyficznego charakteru. Inaczej rozkładają się akcenty wychowawcze, ponieważ uwaga rodziny skupiona jest na cierpiącym dziecku (Godawa, 2013).

Choroba jednego z członków powoduje najczęściej totalną dezorganizację życia rodziny, którą zmusza do tego, aby zacząć funkcjonować w zupełnie inny sposób. Wszystkie działania zostają podporządkowane najważniejszemu celowi, jakim jest leczenie i opieka nad chorym dzieckiem (Godawa, 2013). Jednak nie można zapominać, że wspomniane zmiany, będące typowymi lub nietypowymi, czynią rodzinę bardziej podatną na zaburzenia w jej strukturze, ale i z drugiej strony powodują stworzenie strategii radzenia sobie z owymi trudnymi sytuacjami (Doroszuk, 2017).

Według Kościelskiej (2001, za: Baran, Chojecka, 2009), u rodziców dzieci z niepełnosprawnościami najczęściej pojawiają się trzy, charakterystyczne dla nich, podstawowe uczucia. Pierwszym z nich jest poczucie zranienia psychicznego, które u podłoża ma przekonanie o gorszej pozycji dziecka z dysfunkcją w społeczeństwie. Drugim uczuciem jest zmęczenie, będące wynikiem świadczonej nieustannej opieki na rzecz chorego dziecka. Trzecim uczuciem, jakie najczęściej pojawia się u rodziców dzieci z niepełnosprawnością, jest lęk oraz obawa o to, że dziecko zostanie odrzucone przez otoczenie. W przypadku dzieci przewlekle chorych uczucia te będą tożsame, jednak lęk i obawa mogą być spotęgowane nieprzewidywalną przyszłością, długotrwałym leczeniem i koniecznością hospitalizacji, a czasem zagrożeniem życia.

Omawiając sytuację rodziny, w której wystąpiła choroba przewlekła dziecka, obok omówienia funkcjonowania i przeżyć chorego oraz jego rodziców, nie wolno zapominać o uczuciach, przeżyciach i potrzebach zdrowego rodzeństwa. Jest to niezwykle ciekawa i ważna kwestia, choć zagadnienia te w dalszym ciągu są w literaturze stosunkowo rzadko podnoszone.

Zdrowe dzieci posiadające przewlekle chore rodzeństwo znajdują się w nietypowej sytuacji, która może mieć pozytywny lub negatywny wpływ na ich obecną i przyszłą jakość życia (Boruszak, Gryglicka, 2014). Jak twierdzi Godawa (2013), wciąż nie ma jednoznacznej odpowiedzi, które z tych doświadczeń są bardziej po- 
pularne. Ogromne znaczenie ma w tej sytuacji rola rodziców oraz prawidłowo realizowane zadania rodzicielskie, mające na celu pomoc $\mathrm{w}$ poradzeniu sobie z tym doświadczeniem. Jednak nie ulega wątpliwości, iż rodzicom cierpiącego z powodu dysfunkcji somatycznych dziecka, z powodu wielu obowiązków i obciążeń zarówno organizacyjnych, jak i psychicznych, niełatwo jest prawidłowo dbać o wszelkie potrzeby zdrowego dziecka (Rogiewicz, Paczkowska, 2012).

Choroba brata lub siostry wymusza u zdrowego rodzeństwa konieczność zmagania się z wieloma problemami, zarówno natury logistycznej, jak i fizycznej oraz co wydaje się najważniejsze, psychologicznej.

Rodzeństwo reaguje na chorobę w rodzinie i wraz z cierpiącym bratem czy siostrą przeżywa niepokój i obawę przed nieznanym oraz przed rozpoczęciem terapii czy bólem (Godawa, 2013). Owe emocje może potęgować niewiedza, a także trudności w przyswajaniu i rozumieniu informacji, w kategoriach zdrowie-choroba. Warto pamiętać, że dzieci mają mniejsze zdolności do regulowania tych emocji, dlatego rodzice powinni ułatwiać im wyrażanie uczuć, rozpoznawanie ich źródła i pokazywanie, że wszelkie stany emocjonalne są potrzebne i w jaki sposób możemy sobie z nimi radzić. Brak wymaganej uwagi ze strony rodziców, dodatkowo łączony z trudnymi uczuciami, takimi jak poczucie winy, złość, frustracja, bezsilność czy zawstydzenie, mogą generować u rodzeństwa chorych dzieci eskalację tych emocji i przeniesienie ich na inne osoby.

Rodzeństwo chorego może doświadczać wahania nastroju, żalu czy nawet gniewu (Rogiewicz, Paczkowska, 2012). W obliczu choroby najczęściej jednak opisywane przez braci i siostry dzieci chorych są takie uczucia, jak obawa i lęk przed konsekwencjami choroby, tym co się zdarzy i nieuchronnością losu. Wspomniane uczucia wiążą się także niepewnością tego, co się zdarzy, trudnością z rozumienia zawiłych procedur lekarskich czy postępowania medycznego.

Do znaczących doświadczeń rodzeństwa dzieci chorych zaliczyć można takie jak:

- poczucie winy i samooskarżania się z powodu choroby czy śmierci rodzeństwa;

- niechęć czy unikania chorego;

- żal do chorego, że na nim skupia się uwaga rodziny;

- ulga z powodu dobrego zdrowia, połączona z lękiem przed tym, co może się zdarzyć w przyszłości;

- zniechęcenie obowiązkiem bycia „miłym” oraz „grzecznym” (Eiser, 1993, za: Godawa, 2013).

W postawach zdrowego rodzeństwa mogą także występować liczne niepokojące zachowania świadczące na przykład o zaburzeniach w ich rozwoju (Godawa, 2013). Rodzeństwo dzieci przewlekle chorych lub niepełnosprawnych w większym stopniu narażone jest na znaczące ryzyko wystąpienia różnego typu trudności ada- 
ptacyjnych, zaburzeń czy problemów emocjonalnych, a także utrudnień w tworzeniu relacji z rówieśnikami (Pisula, 2007, za: Boruszak, Gryglicka, 2014).

$\mathrm{Z}$ drugiej strony należy podkreślić, że zdrowe rodzeństwo chorych dzieci posiada wiele zalet, które zostały ukształtowane w przestrzeni choroby. Odznacza się ono wyższym poziomem socjalizacji, altruizmu i ma większą świadomość odmienności pomiędzy ludźmi oraz ich losu. Dzieci te potrafią dostosowywać się do aktualnej sytuacji, są bardziej elastyczne i pełne zrozumienia.

Dodatkowo warto wspomnieć, że choroba może sprzyjać wzrostowi uspołecznia dziecka, rozwojowi jego wrażliwości, empatii i odpowiedzialności za innych, a także zwiększać tolerancję wobec różnic i odmienności w społeczeństwie (Baran, Chojecka, 2009).

Niektóre siostry i bracia chorych dzieci potrafią dostrzec złożoność życia. Dzieci te są zwykle bardziej dojrzałe i samodzielne w porównaniu z rówieśnikami, którzy nie stykają się na co dzień w swoim domu z poważną chorobą. Świadomość odmienności chorego brata czy siostry może pomóc zrozumieć, że każdy człowiek zasługuje na szacunek, niezależnie od stanu zdrowia.

Zdarza się także, iż rodzeństwo dzieci cierpiących na przewlekłe schorzenia somatyczne szybciej staje się samodzielne a niżeli ich rówieśnicy, który nie doświadczają choroby brata lub siostry (Pisula, 2007, za: Baran, Chojecka, 2009).

Sytuacja, funkcjonowanie oraz to, w jaki sposób rodzina poradzi sobie z obciążeniem jakim jest choroba jednego z członków, w dużej mierze zależy od jej zasobów, zaś sukces rodzeństwa w tym zakresie uzależniony jest od wsparcia otoczenia, w tym szczególnie rodziców, opiekunów, ale także środowiska społecznego, otoczenia i bliskich.

Dla potwierdzenia powyższych założeń autorka pragnie pokrótce odnieść się do własnego opracowania badań dotyczących postaw wobec choroby u rodzeństwa dzieci przewlekle chorych, opracowanych w ramach pracy magisterskiej w Instytucie Psychologii Stosowanej Uniwersytetu Jagiellońskiego. Tematyka zbieżna z poruszaną w niniejszym artykule akcentuje szereg złożonych emocji, zachowań oraz przemyśleń dotyczących schorzenia siostry czy brata, jakich doświadczają zdrowe dzieci.

W ramach wspomnianego opracowania wykorzystana została metoda analizy indywidualnych przypadków. Metoda ta pozwala na wnikliwe rozpatrzenie zjawiska, które może być ujmowane przez wybraną grupę badaną jako bardzo intymne lub drażliwe. Autorka posłużyła się kilkoma technikami badawczymi, w tym analizą wytworów, wywiadem oraz techniką kwestionariuszową. Wykorzystano szereg narzędzi badawczych, w tym rysunek chorego brata lub siostry nazwany: „Moje rodzeństwo", kwestionariusz wywiadu, Kwestionariusz Postaw Wobec choroby J. Kostrzewskiego w adaptacji własnej, oraz Dyferencjał Semantyczny i Test Zdań Niedokończonych w adaptacji własnej (Glac, 2018, nie publ.). 
Przeprowadzone zostały jakościowe badania na grupie 10 osób spełniających kryterium bycia zdrowym rodzeństwem dzieci przewlekle chorych, zamieszkujących województwa małopolskie oraz świętokrzyskie. Osoby badane były w wieku od 12 do 18 lat. Uzyskano zgody rodziców osób badanych, a ich udział był dobrowolny i świadomy.

Autorka w swoich badaniach eksplorowała tematykę postaw wobec choroby rodzeństwa odnosząc się do przyjętych w założeniach teoretycznych trzech sfer: poznawczej, behawioralnej oraz emocjonalnej. Zaś dla potrzeb niniejszej publikacji najistotniejszy wydaje się opis tego ostatniego aspektu: doświadczanych emocji, przeżyć.

Odnosząc się do wniosków płynących ze wspomnianego opracowania w kwestii przeżyć oraz funkcjonowania zdrowego rodzeństwa chorych dzieci należy odwołać się do opisywanych powyżej trudności i nieprzyjemnych emocji.

Najczęściej wskazywanymi przez badanych w opisywanym projekcie ciążącymi uczuciami były: smutek, obawa o życie rodzeństwa, lęk przed śmiercią. Ponadto, jak ukazały badania, respondenci doświadczają silnego zaniepokojenia dotyczącego przyszłości zarówno chorego rodzeństwa, jak i rodziców, którzy - jak przewidują wraz z wiekiem będą mieli coraz mniej siły do opieki nad chorą siostrą lub bratem (Glac, 2018, nie publ.). Do podobnych wniosków odwołuje się Boruszczak (2014), wskazując na wyższy poziom lęku u rodzeństwa dzieci nieuleczalnie chorych. Autorka twierdzi, iż lęk ten dotyczy przede wszystkim zdrowia i życia chorujących oraz ujmuje generalnie sytuację rodziny.

Ważnym aspektem, jaki ukazały opisywane badania autorki, jest wniosek dotyczący przyjmowanej przez badanych tendencji do odczuwania samotności i niemożności podzielenia się swoimi trudnymi emocjami z innymi. Taka sytuacja potęguje postawę lękową oraz wewnętrzne napięcie generowane sytuacją zdrowotną rodzeństwa (Glac, 2018, nie publ.).

Warto zauważyć także, że rodzeństwo chorych dzieci, poprzez ich silne związki emocjonalne, może doświadczać trudności z dystansowaniem się od problemów chorego brata czy siostry. Zaś w przypadku dużego zaangażowania uczuciowego w sytuację chorych, badani prawdopodobnie doznają silnych przeżyć w momentach rozdzielenia, ale przede wszystkim zagrożenia życia.

Ponadto bardzo ważnym i ciekawym emocjonalnym przeżyciem jest rozłąka z rodzeństwem, wynikająca z częstej oraz koniecznej hospitalizacji, która była często opisywana przez osoby badane jako sytuacja, w której doświadczają tęsknoty i smutku. Owa obserwacja koresponduje z innymi badaniami. Jak twierdzą Sargent, Sahler, Roghmann (1995, s. 151-164), takie sytuacje rozłąki i osamotnienia są wyzwaniem, z którym muszą radzić sobie zdrowi członkowie rodziny. Jednak jest to zwykle traktowane jako czynnik stresogenny, który może niekorzystnie wpływać 
na dalsze losy tych osób (Glac, 2018, nie publ.). Może być to przyjmowane jako dodatkowy czynnik wpływający na dezorganizację życia i funkcjonowania systemu rodzinnego.

Warty uwagi jest także uwidoczniony przez badanych przeżywany żal, spowodowany niepełnosprawnością rodzeństwa oraz niemożnością pełnego uczestniczenia przez osoby chore zarówno w codziennych obowiązkach, jak i przyjemnościach. Dodatkowo w postawach niektórych badanych osób widoczne było wypieranie bardzo silnych negatywnych emocji (Glac, 2018, nie publ.). W tym miejscu, odwołując się do innych badań (Faux, 1991, s. 175-184), można potwierdzić założenia i wyniki, że rodzeństwu dzieci chorych towarzyszą często takie stany emocjonalne, jak: lęk, smutek, poczucie winy i inne. Uczucia te także zostały wprost opisane przez uczestników przytoczonych badań.

$\mathrm{Na}$ kanwie wspomnianych badań można stwierdzić, że najważniejszym problemem i wyzwaniem osób, które posiadają chore rodzeństwo, jest potrzeba pomocy psychologicznej w wyrażaniu tłumionych trudnych emocji.

Niewątpliwie zasadnym jest dalsze eksplorowanie tematyki funkcjonowania oraz przeżyć rodzeństwa dzieci przewlekle chorych. Ciekawym problemem jest opracowanie najważniejszych aspektów dotyczących trudności i problemów z jakimi muszą mierzyć się każdego dnia.

Dodatkowo, ciekawym tematem pozostają wstępnie opracowane przez autorkę niniejszego artykuły postawy wobec choroby rodzeństwa. Badania te mogłyby zostać poszerzone o większą grupę badawczą z uwzględnieniem podziału na mniejsze grupy wiekowe czy też płeć. Korzystne dla poszerzenia pola eksploracji mogłoby stać się także wykorzystanie innych narzędzi badawczych odnoszących się nie tylko do tematyki postaw wobec choroby, ale także głębokiego ujęcia przeżyć emocjonalnych, podejmowanych czynności pomocowych oraz wiedzy i świadomości na temat choroby rodzeństwa. Warto zaznaczyć, iż samo opracowywanie kwestii postaw daje niezwykle ciekawą przestrzeń do dalszego eksplorowania tej dziedziny o wpływ różnych aspektów życia codziennego na owe postawy, zależności i zmiany w nich zachodzące.

Dzięki dokładnemu zagłębieniu się w tematykę przeżyć i funkcjonowania rodzeństwa dzieci przewlekle chorych możliwe jest opracowywanie nowych, systemowych i ciekawych form pomocy tej grupie. W sferze emocjonalnej pomocne mogą okazać się grupy wsparcia, terapia indywidualna czy też wykorzystanie propozycji rozwoju osobistego czy zainteresowań, dla odreagowywania trudnych przeżyć. Być może dzięki dokładnemu opracowaniu omawianej tematyki możliwe byłoby przygotowanie pomocy terapeutycznych dla przyszłych pedagogów i psychologów podejmujących się pracy z rodzeństwem dzieci przewlekle chorych. Oferty w tym wypadku powinny być dostosowane do potrzeb uczestników, wieku, miejsca zamieszkania, ale także indywidualnych preferencji oraz chęci. 


\section{Potrzeby zdrowego rodzeństwa dzieci przewlekle chorych}

Woda, światło słoneczne czy powietrze są niezbędne do zaspokojenie potrzeb roślin, stanowiąc podstawę ich życia i wzrostu. Podobnie jak człowiek potrzebuje realizacji swoich potrzeb, by zachować zdrowie i móc rozwijać się (Louis, Louis, 2016). Równowaga życiowa i doświadczenie dobrostanu owocuje u każdego człowieka możliwością pełnego korzystania z życia.

Potrzeba może być ujmowana jako proces motywujący związany z pragnieniem, dążeniem lub/i pożądaniem (Kocowski, 1982, za: Krasiejko, 2019). Każdy człowiek ma określone potrzeby, do których zaspokojenia dąży, a których deprywacja doprowadza do utrudnionego funkcjonowania, zarówno fizycznego, psychicznego, jak i społecznego. Potrzeby mogą mieć różnorodną naturę i mogą zawierać się w wielu sferach. Najprostszy podział opiera się na potrzebach dotyczących fizjologii, emocji, spraw socjalnych i bytowych oraz duchowych.

Innym i często przywoływanym podziałem potrzeb jest podział zaproponowany przez Abrahama Maslowa. Wspomniany model hierarchii potrzeb przedstawia uporządkowany ciąg potrzeb od najbardziej podstawowych (wynikających z funkcji życiowych) do potrzeb wyższego poziomu, które aktywizują się dopiero po zaspokojeniu niższych.

Piramidę tworzą:

- potrzeby fizjologiczne;

- potrzeby bezpieczeństwa;

- potrzeby przynależności;

- potrzeby uznania;

- potrzeby samorealizacji.

Opisując powyższe kategorie należy stwierdzić, iż każda istota żyjąca posiada ogólnie potrzeby biologiczne/fizjologiczne. Według Maslowa (2006, za: Kozłowska, 2014) to właśnie one mają największy wpływ na organizm ludzki i sposób jego działania. W przypadku, gdy nie są zaspokojone, dominują nad wszystkimi innymi potrzebami, wypierają je na dalszy plan i decydują o przebiegu zachowania człowieka. W skład potrzeb biologicznych wchodzi koncepcja homeostazy (zautomatyzowane działania organizmu), ale ważna jest również kwestia związana z apetytem, czyli to, co sprawia, że ludzi wolą zaspokoić daną potrzebę w określony sposób (np. wybranie jedzenia ze względu na smak, a nie postrzeganie go tylko jako środka do dostarczenia wartości odżywczych do organizmu). Uściślając można uznać, iż wśród nich znajdują się potrzeba jedzenia, picia, snu, odpoczynku czy ruchu. Ujmowane są one jako potrzeby nadrzędne, pierwszego rzędu, co wiąże się z tym, że ich realizacja powinna być w pierwszej kolejności, jako podstawowa (Krasiejko, 2019). 
Wspomniane powyżej potrzeby bezpieczeństwa co do zasady pobudzają do działania, zapewniając nienaruszalność, ujawniają się, gdy dotychczasowe nawyki okazują się mało przydatne. Zostały one zaliczone przez Maslowa (2006, za: Kozłowska, 2014) do potrzeb braku. Są to potrzeby wrodzone, przejawiające się w początkowej fazie życia przede wszystkim lękiem przed urazami fizycznymi oraz potrzebą opieki i oparcia, a w wyniku procesu uczenia się przenoszone są na inne sfery funkcjonowania. Mają one bardzo silne oddziaływanie motywacyjne, gdyż mobilizują wszystkie organiczne i psychiczne funkcje człowieka (Kozłowska, 2014). Co ciekawe, potrzeby bezpieczeństwa dochodzą do głosu dopiero po zaspokojeniu podstawowych potrzeb fizjologicznych i mają bardzo silny wpływ na jednostkę (Kozłowska, 2014).

Inną grupą potrzeb, zwaną już wyższego rzędu, są te związane z psychiką człowieka, wśród nich znajdą się takie jak: potrzeba kontaktów międzyludzkich, bezpieczeństwa, samodzielności, rozwoju, ale także miłości, szacunku, osiągnięć czy sensu życia (Krasiejko, 2019).

Potrzeby przynależności występują w usiłowaniach przezwyciężenia osamotnienia, alienacji i obcości, tendencji do nawiązywania bliskich intymnych stosunków, uczestnictwa w życiu grupy. Zaś potrzeby uznania i prestiżu dotyczą kategorii widzianych we własnych oczach jednostki i w oczach innych ludzi. Natomiast wspomniane potrzeby samorealizacji wyrażają się w dążeniu człowieka do rozwoju swoich możliwości (Bińczycki, Trętko, 2015).

Jednym z podstawowych warunków prawidłowo przebiegającego rozwoju człowieka jest zaspokajanie potrzeb, zarówno tych fizjologicznych, jak i psychicznych. W przypadku dzieci powinny być one realizowane przede wszystkim przez rodziców, opiekunów w środowisku domowym (Różańska-Gał, Kuś, 2017). Dodać można także do tego wspierającą rolę otoczenia, środowiska społecznego i rówieśniczego.

Na kanwie rozważań w niniejszym artykule odnoszącym się do potrzeb zdrowego rodzeństwa dzieci przewlekle chorych, nie można zapominać, że chore dzieci mają takie same potrzeby jak wszystkie dzieci, jednak może zdarzyć się tak, że realizacja ich będzie wymagała od otoczenia więcej energii i zasobów (Juul, 2004). To samo będzie dotyczyło ich zdrowego rodzeństwa, cierpiącego z powodu dysfunkcji somatycznych dzieci.

Bazowymi i najbardziej znaczącymi będą potrzeby z zakresu wymiaru emocjonalnego, wiązanego z ludzką psychiką. Wymiar ten jest związany ze światem uczuć i myśli. W umyśle osoby chorej, tak jak i jej bliskich, dokonuje się swoiste przeformatowanie sposobu myślenia o sobie i o chorobie (Godawa, 2013).

Emocjonalne potrzeby zdrowego rodzeństwa dzieci przewlekle chorych będą opierały przede wszystkim na kwestii akceptacji, uwagi i pomocy. Mogą też doty- 
czyć zapewnienia poczucia bezpieczeństwa, które ze względu na niekiedy niepewny los i zagrożenie życia siostry czy brata może być mocno zachwiane. Dodatkowo, zdarza się, że rodzeństwo w związku z chorobą brata czy siostry przeżywa deprecjację swoich potrzeb na rzecz wszelkich działań podejmowanych dla cierpiącego rodzeństwa. W tej sytuacji nadmierne obciążenie i oczekiwania mogą rodzić frustrację, a nawet agresję wobec chorego brata czy siostry.

Wśród najważniejszych potrzeb emocjonalnych rodzeństwa dzieci, u których stwierdzono chorobę przewlekłą, należą między innymi:

- potrzeba bycia wartościowym człowiekiem swojej rodziny;

- potrzeba opieki i troski ze strony rodziców;

- potrzeba rozwijania własnej integralności oraz poczucia osobistej samodzielności, odpowiedzialności oraz godności (Juul, 2004).

Do powyższych warto dodać bardzo ważne i realizowane przez rodziców potrzeby poczucia bezpieczeństwa i kontaktu z bliskimi osobami, ale także akceptacji, zrozumienia i miłości (Różańska-Gał, Kuś, 2017). Stanowią one podstawę do budowania integralności jednostki i zasobów radzenia sobie z trudnymi sytuacjami w przyszłości.

Zapewnienie realizacji powyższych potrzeb jest niezwykle ważne dla prawidłowego rozwoju człowieka, ale i tworzy podstawę dla budowania odporności psychicznej i właściwego funkcjonowania w społeczeństwie. Zadaniem rodziny jako podstawowej komórki życia człowieka jest spełnianie potrzeb, a rodziców zapewnianie odpowiednich warunków do adaptacji do zmian i życia.

Po dokonaniu powyższych rozważań można wskazać, iż niezwykle ciekawą przestrzenią badawczą pozostaje także kwestia omawianych potrzeb rodzeństwa dzieci przewlekle chorych. Winno być ono zbadane przy dokonaniu odpowiedniego podziału zgodnie z przyjmowanymi założeniami teoretycznymi, ale także w odniesieniu do stopnia ich realizacji i zaspokajania. Ciekawa z pewnością mogłaby okazać się analiza komparatystyczna wyników badanych z różnych grup wiekowych, odmiennych płci czy miejsca zamieszkania, oraz liczby członków rodziny.

Wspomniana analiza i możliwe badania z pewnością przyczyniłyby się do skuteczniejszej pomocy, a w konsekwencji do polepszenia sytuacji rodzeństwa dzieci przewlekle chorych i funkcjonowania całych ich rodzin.

\section{Podsumowanie}

Podsumowując powyższe rozważania należy stwierdzić, iż choroba przewlekła $\mathrm{w}$ rodzinie diametralnie zmienia sytuację oraz sposoby funkcjonowania jej członków. 
Ponadto stanowi ogromne źródło obciążeń natury psychicznej oraz może generować wiele trudnych przeżyć u jej członków. Co więcej, ma ona wpływ nie tylko na bezpośrednio doświadczającego dysfunkcji, ale i na wszystkich jej członków, w tym zarówno rodziców, jak i rodzeństwo. Choroba może mieć wpływ między innymi na realizowanie potrzeb jej członków. Deprecjacja potrzeb u rodzeństwa dzieci przewlekle chorych, przede wszystkich tych emocjonalnych, może mieć negatywny wpływ na ich przyszły rozwój, funkcjonowanie społeczne i zasoby radzenia sobie z sytuacjami trudnymi. Niezwykle ważna zatem pozostaje rola rodziny i oddziaływanie oraz wsparcie rodziców dzieci, zarówno tych chorych, jak i ich zdrowego rodzeństwa. Rodzice poprzez pozytywne stosunki ze wszystkimi dziećmi, stanowią wzór do budowania prawidłowego własnego obrazu oraz stosunków międzyludzkich.

Opierając się na powyższych rozważaniach można stwierdzić, iż niezwykle ważne jest, by zarówno w sferze naukowej, badawczej, ale i praktycznej dokonywać rozważań na temat sytuacji, przeżyć i potrzeb rodzeństwa dzieci przewlekle chorych i w przyszłości w najlepszym z możliwych sposobów móc im pomagać.

\section{Bibliografia}

Baran P., Chojecka E. (2009). Rodzice i rodzeństwo w obliczu zaburzeń rozwoju występujacego u jednego z dzieci. W: W. Brejnak, K.J. Zabłocki (red.), Wczesna diagnoza i wspomaganie rozwoju dziecka $z$ dysfunkcjami. Warszawa: Galia

Binnebesel J., Bohdan Z., Krakowiak P., Krzyżanowski D., Paczkowska A., Stolarczyk A. (2012). Przewlekle chore dziecko w domu. Poradnik dla rodziny i opiekunów. Gdańsk: Fundacja Hospicyjna.

Bińczycki B., Trętko M. (2015). Piramida potrzeb osób z niepetnosprawnościa jako narzędzie zarządzania. Łódź: Zeszyty Naukowe Politechniki Łódzkiej.

Boruszak J., Gryglicka H. (2014). Sytuacja zdrowego rodzeństwa w rodzinie z dzieckiem przewlekle chorym. „Nowa Pediatria”, 3.

Doroszuk J. (2017). Rodzina dziecka z niepetnosprawnościa w badaniu netograficznym. Rekonstrukcja problemowa badań Haliny Borzyszkowskiej. Gdańsk: Wydawnictwo Naukowe Katedra.

Faux S.A. (1991). Sibling relationships in families with congenitally impaired children. „Journal of Pediatric Nursing”, 6(3).

Glac I. (2018). Postawy wobec choroby u rodzeństwa dzieci nieuleczalnie chorych. Niepublikowana praca magisterska, Uniwersytet Jagielloński w Krakowie.

Godawa G., (2013). Hospicyjne wsparcie zdrowego rodzeństwa terminalnie chorego dziecka. „Wychowanie w Rodzinie”, t. VIII (2). 
Godawa G. (2013). Wptyw choroby terminalnej na relacje zdrowego rodzeństwa $z$ chorym dzieckiem. „Pielęgniarstwo i Zdrowie Publiczne”, 3,4.

Godawa G. (2018). Rodzina wobec nieuleczalnej choroby dziecka. Kraków: Wydawnictwo IMPULS.

Jachimczak B., (2011). Dydaktyczne i pozadydaktyczne uwarunkowania efektów nauczania indywidualnego dzieci przewlekle chorych. Kraków: Oficyna Wydawnicza „Impuls”.

Juul J., (2004). Rodzina i dziecko z choroba przewlektą. Podkowa Leśna: Wydawnictwo MiND.

Kiliszek E. (2019). Rodzina wobec zagrożeń. Rodzina wobec szans. Socjopsychopedagogika rodziny. Studium rodziny petnej. Warszawa: Wydawnictwo Difin.

Kozłowska A. (2014). Potrzeby jako system klasyfikacji modeli perswazyjnych - raport badawczy. Warszawa: Wyższa Szkoła Promocji w Warszawie.

Krasiejko I. (2019). Rodzina z dziećmi. Rodzina dysfunkcyjna. Warszawa: Wydawnictwo Difin.

Lipińska-Lokś J. (2012). Choroba przewlekta a zaburzenia emocjonalne i trudności w uczeniu się. W: B. Winczura (red.), Dzieci z zaburzeniami taczonymi. Trudne ścieżki rozwoju. Kraków: Oficyna Wydawnicza „Impuls”.

Louis J.P., Louis K.M. (2016). Potrzeby emocjonalne dziecka. Sopot: Gdańskie Wydawnictwo Psychologiczne.

Olszewski S., Parys K. (2016). Rozumieć chaos. Rzecz o terminach i znaczeniach im nadawanych w pedagogice specjalnej. Kraków: Wydawnictwo Naukowe Uniwersytetu Pedagogicznego.

Różańska-Gał A., Kuś J. (2017). Ja i moje potrzeby. Program kinestetyczno-komunikacyjny dla dzieci ze znaczna lub gtębokq niepetnosprawnościa intelektualna. Gdańsk: Wydawnictwo Harmonia.

Sargent J.R., Sahler O.J.Z., Roghmann K.J. (1995). Sibling adaptation to childhood cancer collaborative study: siblings' perceptions of the cancer experience. "Journal of Pediatric Psychology", 20(2), s. 151-164.

Tanajewska A., Naprawa R., Stawska J. (2014). Praca z uczniami ze specjalnymi potrzebami edukacyjnymi. Poradnik dla nauczycieli. Warszawa: Wydawnictwo Difin.

Topór-Mądry R. (2011). Choroby przewlekte. Obcią̇enie, jakość życia i konsekwencje ekonomiczne. „Zdrowie Publiczne i Zarządzanie”, tom IX, 1, s. 25-49. 


\title{
Netografia
}

http://www.hospicja.pl/hospicjum-dzieciece-dla-rodzicow/potrzeby-zdrowego-rodzenstwa, dostęp: 12.11.2019.

http://www.wiecjestem.us.edu.pl/opieka-paliatywna-i-hospicyjna-czlowiek-wobliczu-nieuleczalnej-choroby-czesc-i, dostęp: 11.12.2019).

\section{Situation, experiences and needs of healthy siblings in families with a chronically ill child}

\begin{abstract}
This article describes the life situation, feelings and needs of siblings of children who have been diagnosed with a chronic disease, which is rarely discussed in the literature.

The definition of chronic disease was described, in a special way based on terminology in the colloquial, medical, psychological and sociological terms. In addition, it describes situations and experiences in families in which a chronic disease occurs, with particular emphasis on siblings of sick children. A significant part of the article deals with the needs of the sisters and brothers of children suffering from long-term, serious somatic diseases.

In conclusion, the author emphasizes the role of parents in shaping the right responses to cope with difficult situations and meet the needs of their children, both the sick and their siblings.
\end{abstract}

Keywords: chronic illness, needs, family, siblings 